\title{
ON A COLLECTION OF MARINE FISHES FROM THE LESSER ANTILLES
}

\author{
BY
}

Dr. J. METZELAAR.

(With 3 Textfigures.)

PREFACE.

This paper contains a record of the marine fishes, collected by Dr. C. J. VAN DER HoRsT, of the Amsterdam University, during his stay at Curacao, April-May 1920 and of those collected by Dr. J. BoEKE in 1905, which were only handed to me after the publication of the "Report on the Fishes, collected by Dr. J. BoEKE in the Dutch West-Indies 1904-1905, with comparative notes on marine fishes of tropical West Africa." The Hague 1919 (Dutch title of separate print: "Over Tropisch Atlantische Visschen"), to which the present paper forms a supplement.

As Dr. VAN DER HORST paid special attention to the coral reefs and their inhabitants, his collection shows a character, totally different from that of Dr. BoEKE, the small, hiding Gobies, Blennies and suckers being comparatively better represented. - Nearly all the samples were secured in the "Caracasbay" and "Spanish water", being two bays in the S. W.-part of the island, which were not investigated by Dr. BoEke. The latter is more closed off from the open sea than the first and its salinity is higher. Consequently, the fauna, although of a true marine character, is a different one. The time has not yet come for a faunistic comparison of all the splendid bays and small harbours of Curaçao, the methods of investigation not having been uniform throughout. Accordingly, of the 7 new species from Curaçao itself, described in our previous paper, only one has been found again this time.

Taken as a whole, the fishfauna of the "Leeward isles" is decidedly a rich one. Starting from the references as given in our previous paper cited above, amounting to 259 species, 32 fresh ones are now added, making a total of 291 species, which to a wonderful extent equals the number of 291 species, given for Portorico by EvERMANN and MARSH (among which are a few nominal ones.) The swarms of edible fishes round about the isles are only waiting for improved modern fishing methods so as to become of considerable economic importance. ... To the 176 species of the "Windward isles" as known from Cope and from our "Report" only 3 new ones are added.

Meanwhile we should bear in mind that our investigators had no means to catch the big pelagic fishes (tarpons, sailfishes and the larger sharks) which causes a considerable gap in the knowledge of our West Indian insular fauna. Attention of future collectors should be drawn to this point.

In the following lines those species, already known as belonging to the fauna are summed up in a list only. A few more details are given about those species which are either new for the Leeward or for the Windward Islands. Among those three new species are decribed. The types belong to the Amsterdam Zoological Museum. The drawings have been made by our fine artist Mr. J. de Veen.

The paper is concluded by a couple of generic diagnoses, omitted in the "report" cited above, the names appearing there as nomina nuda. 
LIST OF SPECIES OF MARINE FISHES, collected by Dr. J. BOEKE and Dr. C. J. vaN DER HoRST, already known for the fauna of the Lesser Antilles.

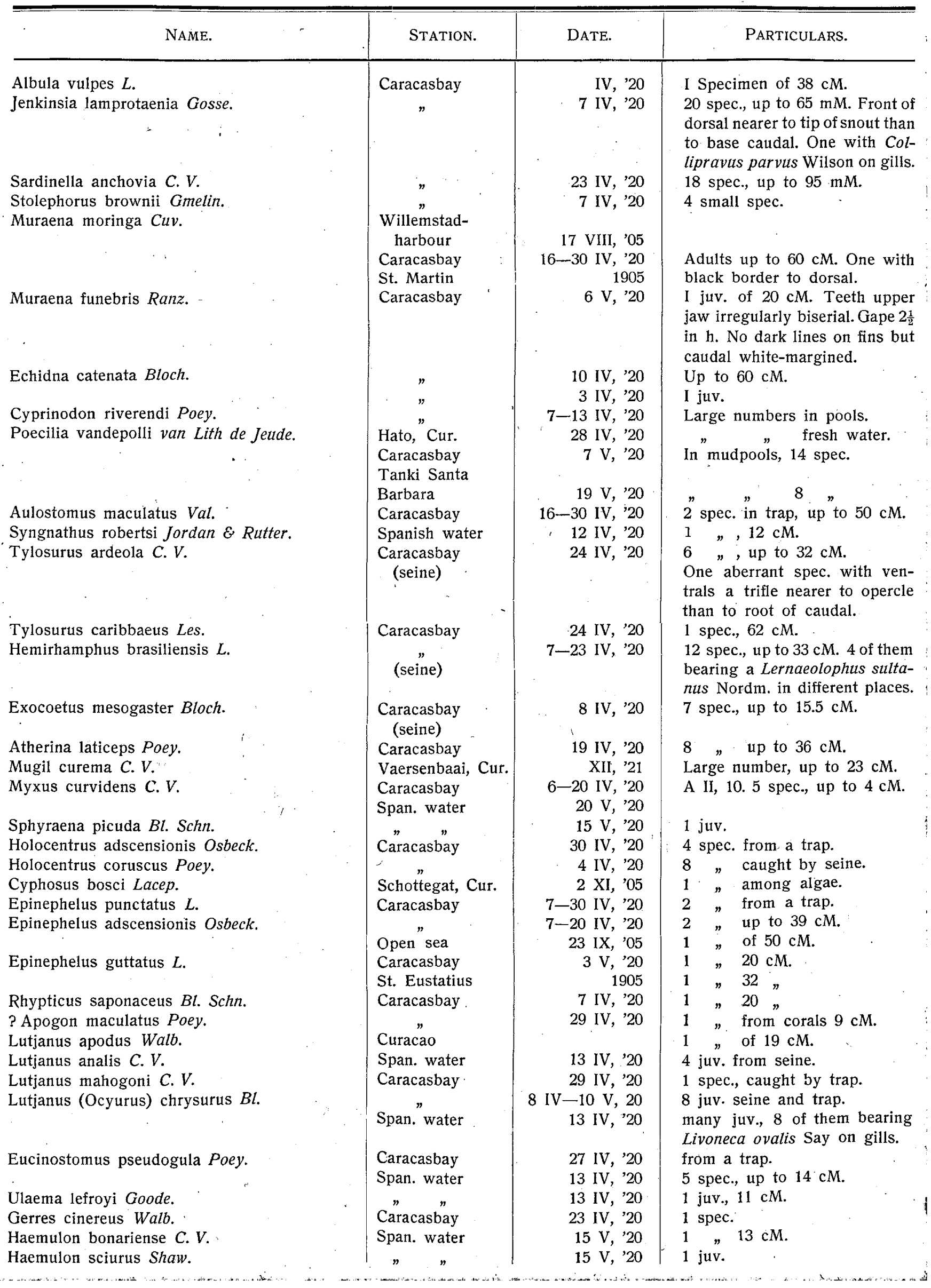




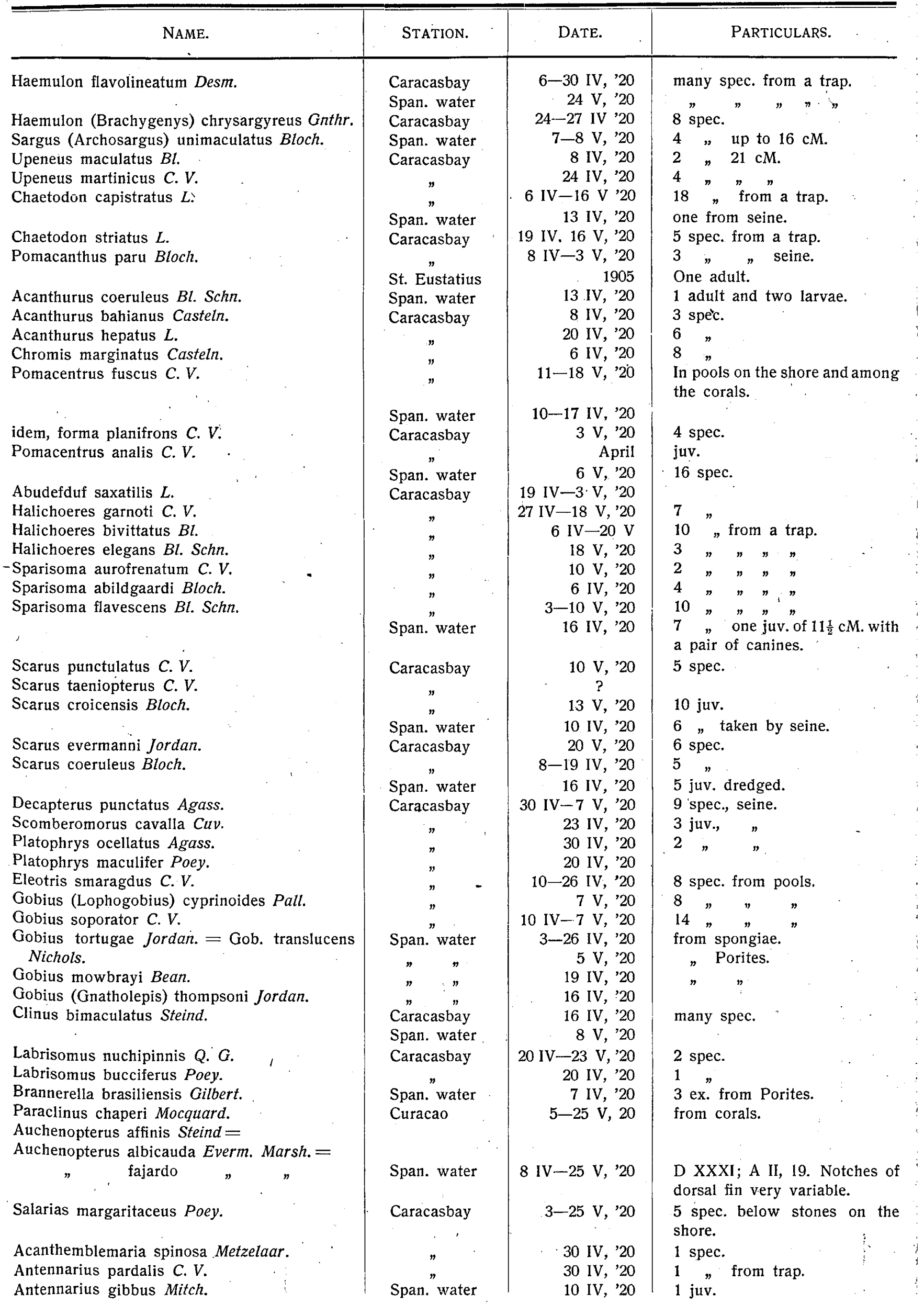




\begin{tabular}{|c|c|c|c|}
\hline NAME. & Station. & DATE. & PARTICULARS. \\
\hline $\begin{array}{l}\text { Balistes vetula } L . \\
\text { Pseudomonacanthus amphioxys Cope. } \\
\text { Ostracion bicaudalis } L \text {. } \\
\text { Ostracion quadricornis } L . \\
\text { Spheroides spengleri Bloch. } \\
\text { Aluteres scripta Osbeck. }\end{array}$ & $\begin{array}{l}\text { Caracasbay } \\
\text { Aruba } \\
\text { Caracasbay } \\
\text { Span. water } \\
\text { Caracasbay } \\
\quad \text { " } \\
\text { Span. water } \\
\text { St. Eustatius }\end{array}$ & $\begin{array}{r}6 \mathrm{IV},{ }^{\prime 20} \\
1905 \\
18 \mathrm{IV}, ' 20 \\
13 \mathrm{IV}, ' 20 \\
27 \mathrm{IV}, ' 20 \\
8 \mathrm{IV}, ' 20 \\
10 \mathrm{IV}, ' 20 \\
19 \mathrm{IX},{ }^{\prime} 05\end{array}$ & $\begin{array}{l}1 \text { juv. } \\
\text { adults up to } 53 \mathrm{cM} . \\
4 \text { spec. } \\
4 \text { " } \\
1 \text { ex. } \\
3 \text { spec. } \\
11 \text { " of } 46 \mathrm{cM} \text {. Nomen indig. } \\
1 \text { "piesjie porco fluit". }\end{array}$ \\
\hline
\end{tabular}

NOTES ON THE SPECIES, NOT YET MENTIONED AS BELONGING TO THE FAUNA OF THE LEEWARD OR OF THE WINDWARD ISLES by COPE Or METZELAAR, (collected by Dr. C. J. VAN DER HORST if not indicated otherwise).

TRYGONIDAE.

\section{Trygon hastata de Kay.}

Two specimens of this well-known W.-Indian ray, of a width of $27-40 \mathrm{cM}$. respectively, were collected by Dr. BoEKe, July 1905, in the "Schottegat" of Curaçao. Nomen indigenum: "Tjutjo blanco".

\section{CLUPEIDAE.}

\section{Stolephorus perfasciatus Poey.}

D. XV, A. XVII. Scales 38 .

7 specimens, up to $7 \mathrm{cM}$. from Caracasbay together with S. brownii and Jenkinsla lamprotaenia.

\section{MURAENIDAE.}

\section{Muraena albimentis Evermann \& Marsh.}

Our supposition on pag. 20 of our "Report" 1919 is confirmed by the catching of a specimen of $5 \mathrm{cM}$. from the corals of Caracasbay on 29 IV 1920 of "Lycodontis albimentis", known from Portorico by Evermann \& MARSH.

\section{4. ? Muraena obscurata Poey.}

One injured specimen with a very high dorsal fin and dark gular folds of $60 \mathrm{cM}$. found in Caracasbay on 16 IV 1920.

\section{Channomuraena vittata Richardson.}

Two fine adult specimens of $75 \mathrm{cM}$. caught by Dr. BoEkE on 19 IX 1905 in the "Reefwater", near the entrance of the harbour of the capital. Nomen indig.: "Rey di colebra", i. e. "king of the snakes".

\section{BERYCIDAE.}

6. Holocentrus tortugae Jordan \& Thompson.

Bull. Bureau Fisheries for 1904, p. 236.

D. Xl, $12 \frac{1}{2}$, A. IV, 8. L. 1. 42 .

Head 3 in length without caudal, depth $3 \frac{1}{2}$. Eye very large, $2 \frac{2}{3}$ in head. Snout 2 in eye. Maxillary reaching middle of eye. Interorbital 4 in head. Suborbital serrate; opercle with 2 flat spines. Preopercle with a rather strong spine; 3-4 rows of scales on cheek. Third dorsal spine 2 in head, 
equalling height of soft dorsal, which is not falcate. Third anal spine very long and strong, $12 / \tau$ in head, equalling depth of fish. Second soft ray little produced. Pectoral = ventral, $1^{2} / 3$ in head. Caudal lobes subequal.

Colour: evident yellow stripes along the rows of scales, here and there bordered by faint rows of black dots. A jet-black blotch between the foremost 3 or 4 dorsal spines, not reaching base of fin, very characteristic for the species, combined with the slender form.

2 specimens of this apparently rare species, measuring $12 \frac{1}{2} \mathrm{cM}$. caught in Caracasbay, April $4^{\text {th }} 1920$.

\section{SERRANIDAE.}

\section{Epinephelus (Dermatolepis) inermis C. V.}

Depth 3 in total. A patch of ctenoid scales above pectoral fin.

One specimen of $16 \mathrm{cM}$. of this rare species from Caracasbay, caught in a trap on 8 IV 1920.

\section{Epinephelus (Mycteroperca) calliura Poey.}

One specimen of this species, which is probably identical with Mycteroperca bowersi Evermann \& Marsh, collected by Dr. J. BoEkE at St. Eustatius, 1905. Length $56 \mathrm{cM}$. Nomen indig.: "Olitu".

\section{Epinephelus flavolimbatus Poey.}

The specimen, called "meru": by the natives and which had been lost and conjectured to be Epinephelus morio C. V. on pag. 48 of our "Report" of 1919 has been found back again and proved to be Ep. flavolimbatus Poey. It was caught on the Pargobank near Aruba, 3 VIII 1905 and has a length of $41 \mathrm{cM}$.

\section{Epinephelus (Mycteroperca) ruber Bloch.}

One specimen was collected by Dr. BoEKE in 1905 at St. Eustatius. Length $35 \mathrm{cM}$.

\section{LUTJANIDAE.}

11. Aprion macrophthalmus Mull. Trosch.

One specimen was collected by Dr. BoeKe at St. Eustatius in 1905. Length $45 \mathrm{cM}$.

12. Etelis oculatus C. V.

One specimen of $60 \mathrm{cM}$. collected at Curaçao on 23 VI 1905 by Dr. BoEke. Nomen indig.: "Sabernetje".

\section{SCIAENIDAE.}

13. Corvina dentex C. V.

One specimen of $15 \mathrm{cM}$. with a jet-black axil collected at Caracasbay April 1920.

\section{MAENIDAE.}

14. Inermia vittata Poey.

D.. XIII, 12. A. III, 8.

Life colour: deep blue with a golden streak round the head.

In some years appearing in swarms at Curaçao, especially in December-January, disappearing suddenly again, sometimes for years. Our 5 specimens caught in April by the natives, who call it "Pesca disconosie", i. e. "the unknown fish". Length $17.5 \mathrm{cM}$.

\section{CHAETODONTIDAE}

\section{Chelmon aculeatus Poey.}

D. XIII, 20. A. III, 16.

A median dark streak on snout and between eyes. Basal parts of soft dorsal dark, bordered by two submarginal black lines. A few specimens caught by trap in Caracasbay, 6 IV 1920. 
SCARIDAE.

16. Sparisoma radians $\mathrm{C}$. V.

. One specimen collected in Spanish water on $15 \mathrm{~V} 1920$.

17. Sparisoma emarginatum Poey.

Head 4 in total; depth $3 \frac{1}{3}$; pectoral 5.2 specimens from a trap in Caracasbay, $121 / 2 \mathrm{cM}$. on $20 \mathrm{~V} 1920$.

TRICHIURIDAE.

18. Trichiurus lepturus L.

One specimen of $80 \mathrm{cM}$. collected by Dr. BoEKe in the open sea off the harbour of Curaçao, called by the natives "zwarte sjouwer", which means: "black dockhand".

SCOMBRIDAE.

19. Thynnus thynnus L.

Two juv. of $53 \mathrm{cM}$. in the open sea off Willemstad, Curaçao, collected by Dr. Boeke. Nomen indig.: "Abrico".

\section{PLEURONECTIDAE.}

20. Platophrys ellipticus Poey.

I juv. caught in the Spanish water, 17 IV 1920.

\section{GOBIIDAE}

\section{Gobius stigmaturus Goode \& Bean.}

D. VI, $10 \frac{1}{2} ;$ A. 11 .

A delicate membrane uniting ventrals. The species seems to be closely related to Gobius glaucofraenum Gilb., perhaps the same. 13 specimens were collected in the Spanish water on 3 IV 1920.

\section{Gobitus lyricus Girard.}

4 specimens with very evident canines collected in Caracasbay and Spanish water 7-19 May 1920.

23. Gobius hipoliti nov. spec.

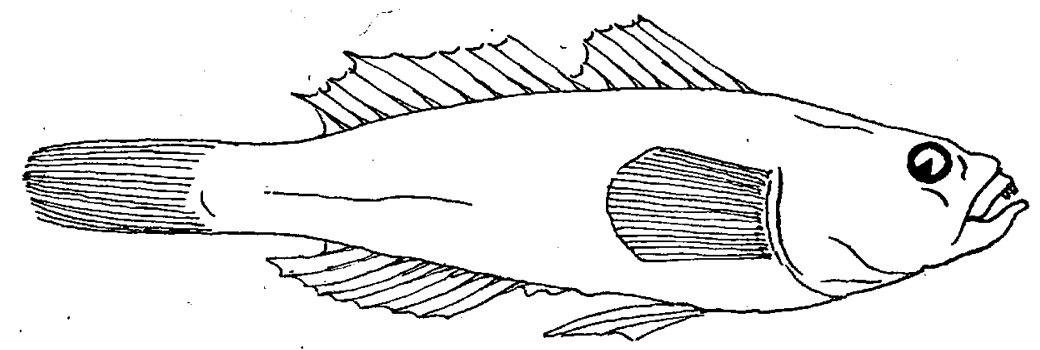

Fig. 1. Gobius hipoliti nov. spec. $\times 3 \frac{1}{2}$.

D. VI, 11; A. X. L. 1. about 27.

Body compressed, 3 in total length; depth 4 . Profile slightly convex. Eye $2 \%$ in head, the eyes not contiguous. Nape fully scaled, without dermal fold. Maxillary oblique, reaching past front margin of eye; lower jaw projecting. Outer teeth enlarged. $1 \frac{1}{2}$ rows of pores on preopercle, 1 vertical and 1 oblique one on opercle. First dorsal fin slightly filamentous; largest ray of second dorsal 6 in total length. Caudal rounded, the depressed rays of dorsal and anal not reaching its root. Ventrals reaching vent. Scales ctenoid. 
Colours faded. Fins speckled. One injured specimen (屯) of $28 \mathrm{mM}$. from corals in Caracasbay, $5 \mathrm{~V}$ 1920. (N.B. The dorsal filament in adults probably longer than in the specimen figured here).

Named after its native collector.

\section{Garmannia rubra Rosèn.}

Lunds Universitetsårsskrift Ny Följd, VII 1911, No. 5, p. 63.

Many specimens from sponges in Caracasbay $10 \mathrm{~V}$ '20 and Spanish water 26 IV 1920.

25. Gobiosoma horsti nov. spec.

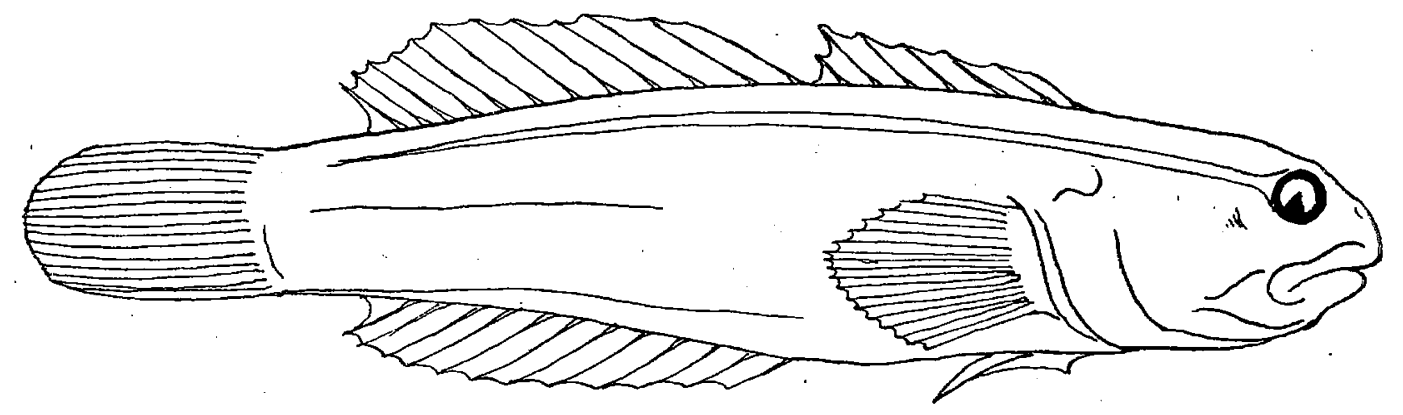

Fig. 2. Gobiosoma horsti nov. spec. $\times 21 / 2$.

D. VII, 12-13; A. $12-13$.

Head $3 \%_{2}$. Depth $4 \frac{1}{3}$. Body compressed. Profile steep. Eye moderate, equal to snout and exceeding interorbital in width. Mouth rather oblique, maxillary reaching past eye. Snout depressed, obtuse; no barbels, but series of minute, elevated pori on head: 2 median ones between eyes, 2 behind eye and a branched row of them on opercle. - Teeth small, outer row enlarged. No scales discernible anywhere. $\rightarrow$ Fins rather high, but without elongated rays. Caudal truncate. Ventrals minute, pectorals reaching back just as far as first dorsal. Colour in spirits blackish with a chalky-white line, extremely sharply defined, by which the species is at once characterised. It runs from upper edge of eye below the dorsal back straight on to caudal base. Two specimens of $55 \mathrm{mM}$. from a sponge, Caracasbay, 3 V 1920.

Named after its discoverer Dr. C. J. VAN DER HORST.

\section{SCORPAENIDAE.}

\section{Pontinus spec.?}

D. XII, 10; A. III, 5. P. 6(!) 21 pori in L.1.

Nasal, suborbital, supraorbital, nuchal, preopercular, opercular, humeral and scapular spines well developed. No filaments. Pectoral very long, reaching past anal root. It resembles closely Scorpaena inermis $\mathrm{C}$. V. but the length of $29 \mathrm{mM}$. does not allow exact specific identification.

Two specimens from a sponge, Caracasbay, $10 \mathrm{~V} 1920$.

\section{GOBIESOCIDAE.}

Our knowledge of this family being very unsatisfactory so long as a critical revision is failing, the determinations must be accepted with some reserve. We are much obliged to Prof. D. S. JoRDAN for his kind assistance. The present collection of Dr. VAN DER HORST is one of the best we ever met with.

27. Gobiesox cephalus Lacep.

D. 7, A. 7. Colour olive. Two specimens of Caracasbay, 1 V'20. 
28. Gobiesox cerasinus Cope.

Upper teeth in one row. D. 11 ; A. 6 ; P. 23. Colour fiery red.

3 specimens beneath stones in Caracasbay, $3 \mathrm{~V} 1920$. The species is perhaps identical with G. carneus Poey, after Jordan.

\section{Gobiesox macrophthalmus Günther.}

1 Specimen from Caracasbay, 8 V 1820.

30. Gobiesox punctulatus Poey.

3 Specimens from Caracasbay, 19 V 1920.

\section{Gobiesox nigripinnis Peters}

D. 11 ; A. 6; P. 22. - Dorsal stretching considerably forward. Colour olive with black spots, elongating behind.

Many specimens collected below stones, Caracasbay 20 IV 1920. The species may be identical with $G$. nudus Bl. Schn. It resembles in fact very much the Curaçaoan specimens appearing with that name in our collections.

32. Gobiesox vittatus nov. spec.

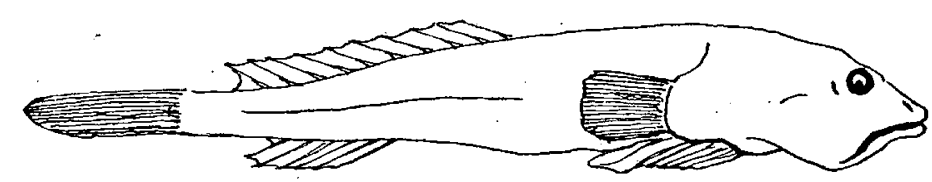

Fig. 3. Gobiesox vittatus nov. spec. $\times 3^{1 / 2}$.

D. 11 ; A. 6 ; P. 23. Head not much compressed, 3 in length; width $3 \frac{1}{3}$. Eye equal to snout, $1 \%$ in interorbital. Teeth of upper jaw in one row, those in lower jaw distinctly flattened. Buccal cleft extending to pupil. - Distance from origin of dorsal to that of caudal exceeding half of the distance from snout to origin of dorsal. Pectoral base with a vertical dermal fold.

Colour brownish red, the head lighter with black points and larger spots, of which a couple are radiating from eye. A darker transverse band in humeral region alternating with a silvery one in pectoral region. Whole body minutely punctulated (in spirits).

One specimen of $29 \mathrm{mM}$. below, stones, Caracasbay, May '20.

BLENNIIDAE.

\section{Starksia cremnobates Gilb.}

D. XXII, 6 or 7 (injured !); A. II, 18; L.1. 40.

Colour olivaceous with rows of black spots at dorsal, caudal, anal and pectoral bases. Black dots around eyes and along the preopercular edge.

One specimen of $4 \mathrm{cM}$. from a sponge in Caracasbay, $10 \mathrm{~V}$ '20, agreeing pretty well with the description of Gilbert.

34. Blenn uls truncatus Poey.

1 Specimen 20 IV 1920, Curaçao.

\section{5.? Hypleurochilus geminatus Wood.}

D. XI, $13-14$; A. $16 ; 4$ small ocular tentacles. 


\title{
MONACANTHIDAE.
}

\author{
36. Monacanthus tuckeri Bean.
}

Several specimens from Caracasbay, 6 IV 1920 and Spanish water, 10 IV '20.

\section{GENERA NOVA.}

(vide Preface).

Melanorhinus.

\section{ATHERINIDAE.}

A genus, probably nearest to Thyrina Jordan \& Culver. Body high, with compressed belly, forming a kind of keel. Mouth terminal, strikingly small and oblique, with jaws of equal length and freely protractile premaxillaries. Vomer without visible teeth. Pectorals moderate, not elongated.

Type: Melanorhinus boekei Metzelaar, "Report on the fishes, collected by Dr. J. Boeke in the Dutch West-Indies, 1904-1905", Hague 1919 pag. 38, caught in an oysterpond at St. Martin.

\section{GOBIIDAE.}

Evermannichthys.

Form exceedingly slender, like that of an eel, the depth being contained about 10 times in the total length. Body naked, save the basal parts of caudal peduncle, which are covered with rather large, ctenoid scales. An aberrant goby, specialised to inquiline habits of life.

Type: Evermannichthys spongicola Metzelaar, living in sponges in bay at Curaçao. "Report", etc. pag. 139.

Xenogobius.

General form rather compressed; body covered by minute scales, except a patch of larger scales in a sharply-defined area under pectoral. Lateral line ascending from ventral region to middle of tail. Mouth large and oblique. Pectoral with seven spines; caudal rhombic and pointed.

Type: Xenogobius weberi Metzelaar. "Report" etc. pag. 140, caught in the Reefwater of Curaçao.

\section{BLENNIIDAE.}

\section{Histioclinus.}

Body compressed, much like Gunellus. Aberrant genus of Blennies characterised by a large, velum-like appendage extending from the large mouth, reaching to edge of preopercle, much like in the Pacific genus Neoclinus Girard, differing from that genus chiefly in the confluence of the three vertical fins, the smaller pectorals (which are contained about twice in head) and the larger scales, of which there are about 60 transverse rows.

Type: Histioclinus veliger Metzelaar. "Report", etc. pag. 157 which inhabits in large numbers the lake of Bonaire, not exceeding $35 \mathrm{mM}$.

\section{Acanthemblemaria.}

A highly specialised genus of blennies, characterised by the strong spines on front and top of head, surrounding the eyes and the strong teeth in the large mouth, which are placed in one row in the upper jaw, a few villiform ones being located behind the front row in the lower jaw. Ocular filaments present.

Type: Acanthemblemaria spinosa Metzelaar. "Report", etc. pag. 159. A small fish from Curaçao. 